\title{
A New Method to Prepare Rabbit Immune Anti-M and -N Sera Using Blood Group Substance Trapped in Autologous Red Cell Ghost as an Immunogen
}

\author{
Tsuyoshi Yokoi, Mineo Iwasa and Kaoru Sagisaka \\ Department of Legal Medicine, Gifu University School of \\ Medicine, Gifu 500
}

\begin{abstract}
Yokor, T., Iwasa, M. and Sagisaka, K. A New Method to Prepare Rabbit Immune Anti-M and - $N$ Sera Using Blood Group Substance Trapped in Autologous Red Cell Ghost as an Immunogen. Tohoku J. exp. Med., 1983, 140 (3), 289-296 - To prepare anti-M and - $\mathrm{N}$ of a sufficient potency, $\mathrm{M}$ or $\mathrm{N}$ substance trapped in autologous ghost was intravenously administered to rabbits. The potency and specificity of antisera prepared were compared with antisera prepared by other immunization methods. Rabbits immunized intravenously or intramuscularly with $\mathrm{M}$ or $\mathrm{N}$ substance alone produced no significant antibodies. Immunization with the substance loading ghost produced crude antisera of relatively low titers, but they were proved to contain specific anti-M and - $\mathrm{N}$ after absorption procedure which were higher than those prepared by usual intravenous injection of red cells. There was remarkable difference in immunoglobulin class between antisera prepared with the substance loading ghost and that by red cell immunizations; the former consisted of $\operatorname{IgM}$ and $\operatorname{IgA}$, and the latter of $\operatorname{IgG}$ and $\operatorname{IgA}$. It was considered that intravenous injection of the antigen trapped in ghost is useful for preparing hemagglutinin of sufficient titers. - - - MN blood group; antigen trapped in ghost; hemagglutinin
\end{abstract}

Since Landsteiner and Levine discovered MN blood group system in 1927, anti$\mathrm{M}$ and $-\mathrm{N}$ have been prepared from numerous kinds of sources; human, animals and lectins. According to the review of Prokop and Uhlenbruck (1969), spontaneous anti-M and $-\mathrm{N}$ were pointed out in human, monkey, horse, pig, rabbit and so on. To prepare immune animal antisera, many routes for immunization have been adopted; intravenous, intramuscular and intraperitoneal (Davidson and Rosenfeld 1939; Ikin 1954). According to our experiences, immune hemagglutinins of a high titer were obtained by intravenous injection of immunogen rather than intramuscular one, whereas immune precipitins were induced frequently by intramuscular immunization. For preparation of rabbit anti-M and $-\mathrm{N}$, intravenous injection of human red cells has been carried out as described originally by Landsteiner and Levine $(1927 \mathrm{a}, \mathrm{b})$. However, the resulting antisera contained potent antibodies other than MN blood group system which should be eliminated by repetitious absorptions. In this paper, we attempted to establish a new immunizing method

Received for publication, November 2, 1982. 
in which $\mathrm{M}$ or $\mathrm{N}$ substance trapped in rabbit red cell ghost was employed as the immunogen. The potency and specificity of the resulting antisera were compared with those prepared by other methods.

\section{Materials and Methods}

$M$ and $N$ blood group substances. O.M or O.N red cells were washed with saline several times and lysed with distilled water. The resulting stroma was adequately washed with distilled water and crude blood group substance was prepared by the method of Nagai and Springer (1962). The substance $(200 \mathrm{mg})$ was dialyzed against $0.01 \mathrm{M}$ phosphate buffer $\mathrm{pH} 7.5$ containing $0.2 \%$ sodium laurylsulfate (SDS) and applied on a column of Sepharose $6 \mathrm{~B}(3.0 \times 70 \mathrm{~cm}$ in size $)$ which was equilibrated with the same buffer. Further purification was performed with CM-Sephadex C-50 $(2.0 \times 30 \mathrm{~cm})$ and DEAE-cellulose (Whatman DE32) column $(2.0 \times 30 \mathrm{~cm})$ chromatographies using $0.02 \mathrm{M}$ acetate buffer $\mathrm{pH}$ 4.8, 0.02 M Tris-HCl buffer $\mathrm{pH} 8.0$ and $0.02 \mathrm{M}$ Tris-HCl buffer $\mathrm{pH} 8.0$ containing $0.5 \mathrm{M}$ $\mathrm{NaCl}$, respectively. Blood group activity of the substance was checked by an agglutination inhibition method.

Trapping of $M$ or $N$ substance into red cell ghosts. The trapping was performed as described by Furusawa (1980). Rabbit red cells were washed with phosphate buffered saline (PBS: $137 \mathrm{mM} \mathrm{NaCl}, 2.7 \mathrm{mM} \mathrm{KCl}, 8.1 \mathrm{mM} \mathrm{Na} \mathrm{HPO}_{4}, 1.5 \mathrm{mM} \mathrm{KH} \mathrm{PO}_{4}$ and $4.4 \mathrm{mM}$ $\mathrm{MgCl}_{2} \mathrm{pH} 7.2$ ), followed by washing with phosphate buffered saline containing $\mathrm{KCl}$ of high concentration (K-PBS: $137 \mathrm{mM} \mathrm{KCl}, 2.7 \mathrm{mM} \mathrm{NaCl}, 8.1 \mathrm{mM} \mathrm{Na} \mathrm{HPO}_{4}, 1.5 \mathrm{mM} \mathrm{KH}_{2} \mathrm{PO}_{4}$ and $4.4 \mathrm{mM} \mathrm{MgCl}, \mathrm{pH} \mathrm{7.2)}$. One volume of the ghost was mixed with 9 volumes of K-PBS containing $\mathrm{M}$ or $\mathrm{N}$ substance $(0.62 \mathrm{mg} / \mathrm{ml})$ and dialyzed against $1: 6$ diluted $\mathrm{K}$-PBS for $1 \mathrm{hr}$ and then against $\mathrm{PBS}$ for $1 \mathrm{hr}$ at $4^{\circ} \mathrm{C}$. In the second dialyzing step, the ruptured membrane was sealed and the substance was trapped in the ghosts. The ghosts were washed with PBS, and the $\mathrm{M}$ or $\mathrm{N}$ activity was examined by the elution method. The ghosts were dropped on gauze and fixed by heating at $100^{\circ} \mathrm{C}$ for $10 \mathrm{~min}$, followed by examination with the elution method using a low ionic strength solution (Sagisaka et al. 1980) as an eluting medium.

Immunization procedure. Randomly bred rabbits were used. Group 1: Intravenous injection of blood group substance trapped in rabbit ghost. One $\mathrm{ml}$ of $\mathrm{M}$ or $\mathrm{N}$ substance trapped in ghost was injected twice a week for 5 weeks. Some of the rabbits immunized with booster injections in which $1 \mathrm{ml}$ of $10 \%$ suspension of O.M or O.N red cells was injected intravenously once a week for 2 weeks. Group 2: Intravenous injection of red cells. One $\mathrm{ml}$ of $10 \%$ suspension of O.M or O.N red cells was injected daily for 35 days. Group 3 : Intramuscular injection of blood group substance. Two $\mathrm{ml}$ of $\mathrm{M}$ or $\mathrm{N}$ substance $(\mathrm{l} \mathrm{mg} / \mathrm{ml})$ was injected twice a week for 5 weeks. At the initial two injections, emulsion with Freund's complete adjuvant was injected. Group 4: Intravenous injection of blood group substance. Two $\mathrm{ml}$ of $\mathrm{M}$ or $\mathrm{N}$ substance $(1 \mathrm{mg} / \mathrm{ml})$ was injected twice a week for 5 weeks.

In the intravenous injections (Groups 1, 2 and 4), $1 \mathrm{ml}$ of Freund's complete adjuvant was intramuscularly injected at the first two weeks separately. Ten days after the last injection, all the rabbits were bled.

Absorption of antisera. Inactivated anti-M sera were absorbed with one-tenth volume of red cell of $\mathrm{O} . \mathrm{N}$ group and vice versa, at $4^{\circ} \mathrm{C}$ for $1 \mathrm{hr}$ repeatedly.

Separation of immunoglobulin class. Antisera were fractionated by DEAE-cellulose chromatography as described by Abelson and Rawson (1963).

Analytical procedure. Sialic acid was determined by the direct Ehrlich method (Werner and Odin 1952) in which $\mathrm{N}$-acethylneuraminic acid was used as a standard. 


\section{Results}

Blood group substance and its trapping into ghost

As shown in Fig. 1, Sepharose 6B chromatography gave two fractions (Fr. 1 and Fr. 2); Fr. 1 was composed of much proteins and little sialic acid, and Fr. 2 much amount of sialic acid. $\mathrm{M}$ or $\mathrm{N}$ blood group activity was detected in only Fr. 2. The blood group active fraction was applied on CM-Sephadex C-50 and then on DEAE-cellulose column. The substance was not absorbed with the former resin but absorbed with the latter one.

After washing adequately, the ghosts containing blood group substance were mixed with rabbit anti-M or $-\mathrm{N}$ in test tubes. No agglutination was observed after centrifugation at 1,000 rpm for 1 min under a phase contrast microscope (Fig. 2 ). Conversely, the elution test on the ghost stains gave clear positive reaction. These findings indicated that the substance was completely trapped in the ghost.

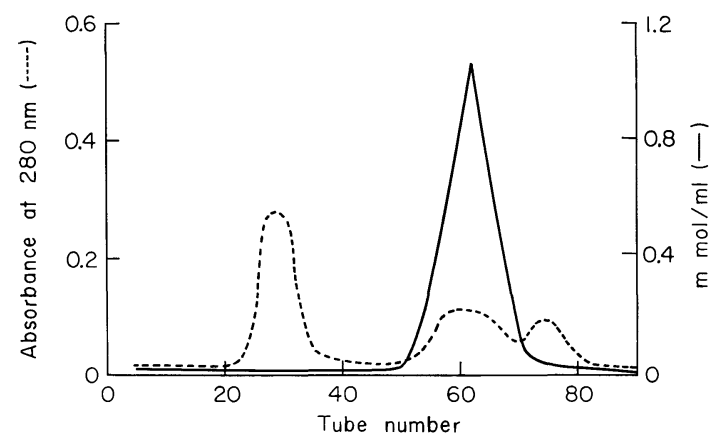

Fig. 1. Chromatography of M substance on Sepharose 6B.

Five $\mathrm{ml}$ of $\mathrm{M}$ substance $(200 \mathrm{mg})$ was applied on a column $(3.0 \times 70 \mathrm{~cm}$ in size $)$. Fractions of $4 \mathrm{ml}$ each were collected. Concentrations of protein (-.--) and sialic acid (-) were measured.

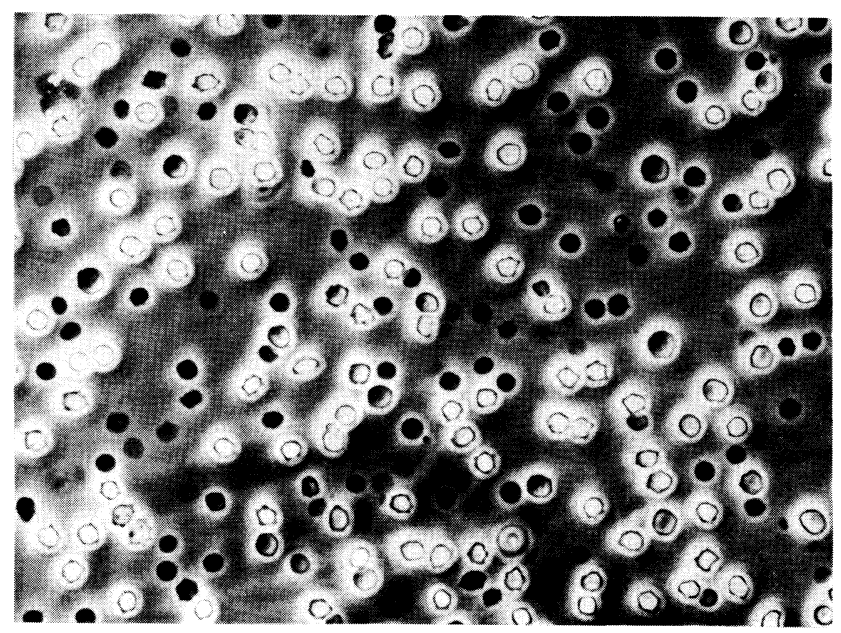

Fig. 2. A photograph showing rabbit red cell ghosts containing $M$ substance observed under a phase-contrast microscope. 
For storage, the substance trapped in ghost was frozen using glycerol solution (Chaplin and Mollison 1953). After being defrozen, considerable decrease of blood group activity occurred and slight agglutination in test tubes was observed owing to ghost lysis.

TABLE 1. Agglutinin activity of crude anti-M and $-N$

\begin{tabular}{|c|c|c|c|c|}
\hline \multirow{2}{*}{$\begin{array}{l}\text { Rabbit } \\
\text { group }\end{array}$} & \multirow{2}{*}{$\begin{array}{c}\text { Antiserum } \\
\text { No. }\end{array}$} & \multirow{2}{*}{$\begin{array}{l}\text { Test } \\
\text { cells }\end{array}$} & \multicolumn{2}{|c|}{ Agglutinin titer $\left(2^{n}, n=\right)$} \\
\hline & & & Before absorption & After absorption \\
\hline \multirow{20}{*}{1} & Anti-M & M & $1: 2,560$ & $1: 64$ \\
\hline & No. 1 & $\mathrm{~N}$ & 1,280 & 1 \\
\hline & Anti-M & M & 5,120 & 128 \\
\hline & No. 2 & $\mathrm{~N}$ & 640 & 1 \\
\hline & Anti-M & M & 80 & - \\
\hline & No. 3 & $\mathrm{~N}$ & 320 & - \\
\hline & Anti-M & M & 1,280 & 160 \\
\hline & No. $4^{*}$ & $\mathrm{~N}$ & 640 & 1 \\
\hline & Anti-M & M & 1,280 & 20 \\
\hline & No. $5^{*}$ & $\mathrm{~N}$ & 640 & 1 \\
\hline & Anti-N & M & 640 & 1 \\
\hline & No. 1 & $\mathrm{~N}$ & 1,280 & 8 \\
\hline & Anti-N & M & 1,280 & 1 \\
\hline & No. 2 & $\mathrm{~N}$ & 5,120 & 64 \\
\hline & Anti-N & M & 2,560 & 1 \\
\hline & No. 3 & $\mathrm{~N}$ & 10,240 & 64 \\
\hline & Anti-N & M & 640 & 1 \\
\hline & No. $4 *$ & $\mathrm{~N}$ & 640 & 32 \\
\hline & Anti-N & $\mathrm{M}$ & 640 & 1 \\
\hline & No. $5^{*}$ & $\mathrm{~N}$ & 2,560 & 160 \\
\hline \multirow{12}{*}{2} & Anti-M & M & 2,048 & - \\
\hline & No. 1 & $\mathrm{~N}$ & 2,048 & - \\
\hline & Anti-M & M & 4,096 & - \\
\hline & No. 2 & $\mathrm{~N}$ & 4,096 & - \\
\hline & Anti-M & M & 8,192 & 64 \\
\hline & No. 3 & $\mathrm{~N}$ & 1,024 & 1 \\
\hline & Anti-N & M & 3,200 & 1 \\
\hline & No. 1 & $\mathrm{~N}$ & 25,600 & 8 \\
\hline & Anti-N & M & 3,200 & 1 \\
\hline & No. 2 & $\mathbf{N}$ & 12,800 & 8 \\
\hline & Anti-N & M & 6,400 & 1 \\
\hline & No. 3 & $\mathrm{~N}$ & 12,800 & 16 \\
\hline \multirow{12}{*}{3} & Anti-M & M & 800 & 1 \\
\hline & No. 1 & $\mathrm{~N}$ & 400 & 1 \\
\hline & Anti-M & M & 400 & 1 \\
\hline & No. 2 & $\mathrm{~N}$ & 400 & 1 \\
\hline & Anti-M & M & 800 & 1 \\
\hline & No. 3 & $\mathrm{~N}$ & 400 & 1 \\
\hline & Anti-N & $\mathbf{M}$ & 200 & 1 \\
\hline & No. 1 & $\mathrm{~N}$ & 400 & 8 \\
\hline & Anti-N & M & 100 & 1 \\
\hline & No. 2 & $\mathbf{N}$ & 400 & 2 \\
\hline & Anti-N & M & 400 & 1 \\
\hline & No. 3 & $\mathrm{~N}$ & 1,600 & 4 \\
\hline
\end{tabular}


TABLE 1. Continued

\begin{tabular}{ccccc}
\hline \multirow{2}{*}{$\begin{array}{c}\text { Rabbit } \\
\text { group }\end{array}$} & $\begin{array}{c}\text { Antiserum } \\
\text { No. }\end{array}$ & $\begin{array}{c}\text { Test } \\
\text { cells }\end{array}$ & \multicolumn{2}{c}{ Agglutinin titer $\left(2^{n}, n=\right)$} \\
\cline { 4 - 5 } & & Before absorption & After absorption \\
\hline & Anti-M & M & 320 & 1 \\
& No. 1 & N & 320 & 1 \\
& Anti-M & M & 640 & 1 \\
4 & No. 2 & N & 640 & 1 \\
\cline { 4 - 5 } & Anti-N & M & 640 & 4 \\
& No. 1 & N & 640 & 1 \\
& Anti-N & M & 320 & 8 \\
\hline
\end{tabular}

* To rabbits booster injections were given (details were in text).

TABLE 2. Immunoglobulin class composition of crude anti-M and $-N$

\begin{tabular}{|c|c|c|c|c|c|}
\hline \multirow{2}{*}{$\begin{array}{l}\text { Rabbit } \\
\text { group }\end{array}$} & \multirow{2}{*}{$\begin{array}{l}\text { Rabbit } \\
\text { No. }\end{array}$} & \multirow{2}{*}{$\begin{array}{l}\text { Test } \\
\text { cell }\end{array}$} & \multicolumn{3}{|c|}{ Agglutinin titer $\left(2^{n}, n=\right)$} \\
\hline & & & IgG & $\operatorname{IgA}$ & $\operatorname{IgM}$ \\
\hline \multirow{16}{*}{1} & Anti-M & M & - & $1: 1$ & $1: 64$ \\
\hline & No. 1 & $\mathrm{~N}$ & - & - & 16 \\
\hline & Anti-M & M & - & 2 & 64 \\
\hline & No. 2 & $\mathrm{~N}$ & - & - & 32 \\
\hline & Anti-M & M & - & 16 & 32 \\
\hline & No. $4^{*}$ & $\mathrm{~N}$ & - & 16 & 16 \\
\hline & Anti-M & M & - & 8 & 32 \\
\hline & No. $5^{*}$ & $\mathrm{~N}$ & - & 8 & 16 \\
\hline & Anti-N & M & - & 4 & 8 \\
\hline & No. 1 & $\mathrm{~N}$ & - & 4 & 16 \\
\hline & Anti-N & M & - & 8 & 16 \\
\hline & No. 2 & $\mathrm{~N}$ & - & 16 & 32 \\
\hline & Anti-N & M & - & 16 & 32 \\
\hline & No. $4 *$ & $\mathrm{~N}$ & - & 32 & 64 \\
\hline & Anti-N & M & - & 1 & 8 \\
\hline & No. $5^{*}$ & $\mathrm{~N}$ & - & 16 & 16 \\
\hline \multirow{8}{*}{2} & Anti-M & M & 64 & 4 & - \\
\hline & No. 1 & $\mathrm{~N}$ & 64 & 4 & - \\
\hline & Anti-M & M & 32 & 4 & - \\
\hline & No. 2 & $\mathrm{~N}$ & 32 & 4 & - \\
\hline & Anti-N & M & 128 & 8 & - \\
\hline & No. 1 & $\mathrm{~N}$ & 128 & 8 & - \\
\hline & Anti-N & M & 64 & 4 & - \\
\hline & No. 2 & $\mathrm{~N}$ & 64 & 4 & - \\
\hline
\end{tabular}

* To rabbits booster injections were given.

Response of rabbits to various immunizations

Rabbits produced antibodies of various titers against $\mathrm{M}$ or $\mathrm{N}$ antigen according to the routes of immunization (Table 1$)$. The most potent antibody $(1: 25,600)$ was produced in the rabbit immunized intravenously with O.N red cells, of which specific anti-N was not so potent $(1: 8)$. At the immunization with $\mathrm{M}$ or 
$\mathrm{N}$ substance alone, neither intramuscular nor intravenous injection induced useful antibodies of sufficient titers. Especially, rabbits did not respond to $\mathrm{M}$ substance. Antisera raised in rabbits immunized intramuscularly with M or $\mathrm{N}$ substance contained precipitin antibody of a relatively low titer against the immunogen which was not group specific. By immunization with $\mathrm{M}$ or $\mathrm{N}$ substance trapped in ghost, crude antisera with not so high titer as those of Group 2 rabbits were obtained. However, specific anti-M and $-\mathrm{N}$ of sufficient titers were prepared by absorption. In general, it was necessary to absorb several times for preparing specific antisera from antisera of Group 2 rabbits, whereas twice absorptions were enough for antisera of Group 1. Booster injections were attempted to increase agglutinin titers in the rabbits of Group 1, resulting in few satisfactory effects.

\section{Immunoglobulin class composition}

Immunoglobulin class separation revealed that most of the antibodies produced in the rabbits of Group 1 were IgM and no IgG was detected. On the other hand, the rabbits of Group 2 raised mainly IgG antibody. In Group 1, twice booster injections did not affect the composition of immunoglobulins (Table 2).

\section{Discussion}

\section{$M N$ blood group substance loading ghost}

Further purification of $\mathrm{M}$ and $\mathrm{N}$ substance with chromatographies revealed that the crude substances contained a large amount of glycoproteins which had no blood group activity. Trapping of blood group substance in ghost was completely performed by gradual hemolysis with 1:6 diluted K-PBS and by sealing with PBS. As the ghost was autologous, troubles in intravenous administration such as embolism and anaphylaxis did not occur.

\section{Immunization}

As for the effect of immunization with blood group substance alone, it was noted that rabbits did not respond to either intramuscular or intravenous injection. In general, it is known that polysaccharides are less antigenic for rabbit. Bendich et al. (1947) reported that purified A and $\mathrm{H}$ substances did not stimulate rabbits. However, Gibbons and Morgan (1954) revealed that the A substance conjugated with protein from some bacteria had potent antigenicity for rabbits.

According to the summary by Williams and Chase (1967) about immunization of rabbit, hapten-specific antibodies were prepared by various immunizing routes. However, the recommended method to prepare hemagglutinin of a high titer was not mentioned. Therefore, we attempted an administration method in which the immunogen was trapped in autologous red cell ghost. Iino and Furusawa (1981) reported that hapten-specific antibody was raised by the method without artifical adjuvant. In the present experiments, anti-M and $-\mathrm{N}$ of sufficient titers were prepared although agglutinin titers of crude antisera of Group 1 were not 
higher than those of Group 2. As for the efficiency of the antigen-trapped ghost method, Iino and Furusawa (1981) suggested that the antigen injected was ingested as a trapped and non-diluted state by macrophages which played a role of trigger of antibody production. In these experiments, intramuscular injection with emulsion of the substance and Freund's complete adjuvant stimulated scarcely the rabbits. Moreover, ghosts of human O.M or O.N red cell were intramuscularly injected in rabbits as preliminary experiments which produced no significant antibodies (not described in Table 1). These findings implied that not only injection of nondiluted antigen but also intravenous administration were necessary to induce hemagglutinin of high titers.

\section{Analysis of immunoglobulin class composition}

DEAE-cellulose chromatography revealed remarkable differences between antisera induced with the antigen-trapped ghost method and those with usual immunization; the former consisted of $\operatorname{IgM}$ and $\operatorname{IgA}$ and the latter of $\operatorname{IgG}$ and $\operatorname{IgA}$. In Group 1, twice booster injections did not affect the class composition. Talmage et al. (1956) and Fink et al. (1963) indicated that the cell lines producing IgM antibody switched over to those producing IgG by repeated sensitizations. Torriginai and Toitt (1965) demonstrated that the rabbit immunized with human thyroglobulin- or $\gamma$-globulin-coated acrylic resin particles produced potent IgM antibody and maintained the antibody synthesis during repeated sensitizations. They explained the phenomena by the finding that the antigen present on particles persisted in macrophages or was efficiently uptaken into the cells. Immunization with $\mathrm{M}$ or $\mathrm{N}$ trapped in ghosts did not evoke the production of IgG antibody. Therefore, it seemed that antigen trapped in ghost was uptaken as a high concentration state in macrophages to stimulate continuous IgM antibody production. However, the mechanism of no production of IgG antibody by this immunization remains unknown.

In conclusion, the intravenous administration of the antigen trapped in ghost is considered to be useful for preparing anti-M and $-\mathrm{N}$ of sufficient titers and the method is recommended for other hemagglutinogens with low antigenic activity.

\section{References}

1) Abelson, N.M. \& Rawson, A.J. (1963) The reactions between blood group antibodies and antisera to purified immunoglobulins. Transfusion, 3, 469-482.

2) Bendich, A., Kabat, E.A. \& Bezer, A.E. (1947) Immunochemical studies on blood groups; Further characterization of blood group $\mathrm{A}$ and $\mathrm{O}$ substances from individual hog stomach. J. Amer. chem. Soc., 69, 2163-2167.

3) Chaplin, H. \& Mollison, P.L. (1953) Improved storage of red cells at $-20^{\circ} \mathrm{C}$. Lancet, 1, 215-218.

4) Davidson, I. \& Rosenfeld, I. (1939) The preparation of anti-M and anti-N testing fluids. Amer. J. clin. Path., 9, 397-413.

5) Fink, C.W., Miller, W.E.,Jr. \& Dorward, B. (1963) The formation of macroglobulin antibody. II. Studies on neonatal infants and older children. J. clin. Invest., 41, $1422-1428$. 
6) Furusawa, M. (1980) Cellular microinjection by cell fusion: Technique and application in biology and medicine. In: International Review of Cytology, vol. 62, edited by G.H. Bourne \& J.F. Danielli, Academic Press, New York, pp. 29-67.

7) Gibbons, R.G. \& Morgan, W.T.J. (1954) Studies in immunochemistry. 14. The isolation and properties of substances of human origin possessing blood-group B specificity. Biochem. J., 57, 283-295.

8) Iino, T. \& Furusawa, M. (1981) An immunization method using antigen entrapped in erythrocyte ghosts. J. immunol. Methods, 42, 319-323.

9) Ikin, E.W. (1954) In: Blood Groups in Man. 2nd ed., edited by R.R. Race \& R. Sanger, Blackwell Sci. Pub., Oxford, pp. 78-80.

10) Landsteiner, K. \& Levine, P. (1927a) A new agglutinable factor differential individual human bloods. Proc. Soc. exp. Biol. Med., 24, 600-602.

11) Landsteiner, K. \& Levine, P. (1927b) Further observations on individual differences of human blood. Proc. Soc. exp. Biol. Med., 24, 941-942.

12) Nagai, Y. \& Springer, G.F. (1962) Partial hydrolysis of isolated blood group M antigen. Fed. Proc., 21, 67.

13) Prokop, O. \& Uhlenbruck, G. (1969) Human Blood and Serum Groups. MacLaren \& Sons, London, pp. 111-149.

14) Sagisaka, K., Yamashita, H., Iwasa, M., Hirata, K. \& Tsugawa, N. (1980) Enhancement of sensitivity of the elution test using a low ionic strength solution. Acta crim. jap., 46, 173-178.

15) Talmage, D.W., Freter, G.G. \& Taliaferro, W.H. (1956) Two antibodies of related specificity but different hemolytic efficiency separated by centrifugation. $J$. infect. Dis., 98, 300-305.

16) Torrigiani, G. \& Toitt, I.M. (1965) The enhancement of $19 \mathrm{~S}$ antibody production by particular antigen. J. exp. Med., 122, 181-193.

17) Werner, I. \& Odin, L. (1952) On presence of sialic acid in certain glycoproteins and gangliosides. Acta soc. med. upsalian., 57, 230-241.

18) Williams, C.A. \& Chase, M.W. (1967) Methods of Immunology and Immunochemistry, vol. 1, Academic Press, New York, pp. 209-221. 